\title{
Korkea satoindeksi ominaista satoisalle tattarilajikkeelle
}

\author{
Marjo Keskitalo $^{1)}$, Elise Ketoja ${ }^{2)}$, Juha-Matti Pihlava ${ }^{2)}$, Markku Kontturi ${ }^{1)}$ \\ ${ }^{1)}$ MTT Kasvintuotannon tutkimus, 31600 Jokioinen, marjo.keskitalo@mtt.fi, markku.kontturi@mtt.fi \\ ${ }^{2)}$ MTT Palveluyksikkö, 31600 Jokioinen, elise.ketoja@mtt.fi, juha-matti.pihlava@mtt.fi
}

\section{Tiivistelmä}

MTT:n Terveyttä tattarista -hankkeen yhtenä tavoitteena oli etsiä uusia, Suomeen paremmin soveltuvia lajikkeita. Suurempien satotoiveiden lisäksi tavoitteena oli selvittää, kuinka paljon lajikkeet sisältävät liukoisia sokereita ja niihin kuuluvia fagopyritoleja sekä D-chiro-inositolia. Tattarille tyypillisten sokereiden on todettu vaikuttavan ihmisten sokeriaineenvaihduntaan, ja siksi niille saattaisi löytyä nykyistä laajempaa käyttöä diabeetikkojen ja ylipainoisten ruokavaliossa.

Jokioisissa tutkittiin kahtena vuotena (2003 ja 2007) 21 Puolasta, Suomesta, Tšekistä ja ValkoVenäjältä saadun lajikkeen sadontuottoa ja laatua. Koevuodet erosivat selvästi, sillä vuonna 2003 keskimääräiset hehtaarisadot vaihtelivat 636 - 1319 kg:n ja vuonna 2007612 - 2233 kg:n välillä lajikkeesta riippuen. Ensimmäisenä vuonna valkovenäläiset 'Karmen' (1319 kg/ha) ja 'Anita' (1251 $\mathrm{kg} / \mathrm{ha}$ ) tuottivat suuremman sadon verranteena olleeseen 'Ilkkaan' (1106 kg/ha) nähden. Toisena vuonna 'Anitan' (2233 kg/ha) ja 'Karmenin' (2054 kg/ha) lisäksi myös puolalaiset 'Luba' (2036 kg/ha), 'Kora' (2016 kg/ha), 'Panda' (1997 kg/ha) sekä valkovenäläiset 'Vlada' (1984 kg/ha) ja 'Zadanne' (1875 $\mathrm{kg} / \mathrm{ha}$ ) tuottivat verrannetta enemmän. Pähkyläsadon osuutta kuvaavat satoindeksit vaihtelivat 0.14 0.28 välillä lajikkeesta riippuen. Sadoltaan parhaat lajikkeet sijoittuivat myös satoindeksivertailussa parhaimmistoon. Pisimmillä lajikkeilla satoindeksit jäivät muita pienemmiksi. Lajikkeesta riippuen liukoisten sokereiden (ilman sakkaroosia) keskimääräiset pitoisuudet olivat $510-720 \mathrm{mg} / 100 \mathrm{~g}$, josta fagopyritolit muodostivat suurimman yksittäisen ryhmän $(346-617 \mathrm{mg} / 100 \mathrm{~g})$. Fagopyritoleista fagopyritoli B1:tä oli eniten (noin $70 \%$ ). Vapaana ja fagopyritoleissa sitoutuneena olevaa D-chiroinositolia määritettiin $192-324 \mathrm{mg} / 100 \mathrm{~g}$. Suurimmat fagopyritolipitoisuudet löytyivät sadoltaan heikompien lajikkeiden joukosta.

Muiden maiden kasvuoloihin jalostettuja tattarilajikkeita voidaan tutkimuksen mukaan viljellä onnistuneesti myös Suomessa. Kahtena koevuotena kokeissa olleiden lajikkeiden joukosta erottui nykyisin Suomessa viljeltäviä paikalliskantoja satoisampia jalosteita. Erityisesti 'Karmen' ja 'Anita' ovat varteenotettavia lajikkeita, koska ne tuottivat merkitsevästi suurempia satoja molempina koevuosina. Valkovenäläisten jalosteiden lisäksi myös tutkimuksen puolalaiset lajikkeet olivat toisena koevuotena hyviä. Suuren hehtaarisadon tuottaville lajikkeille oli ominaista, että ne löytyivät yleensä matalien ja keskipitkien joukosta, joiden satoindeksi oli myös suurin. Ravitsemuksellisesti mielenkiintoisia liukoisia sokereita kuten fagopyritoleja ja $D$-chiro-inositolia voidaan Suomessa tuottaa vertailukelpoisesti ulkomaisiin tuloksiin verrattuna. Koska hitaasti imeytyviä tattarisokereita saattaa olla vähemmän runsassatoisissa lajikkeissa, on tämä huomioitava lajikevalintoja tehtäessä.

\section{Asiasanat}

Tattari, Fagopyrum esculentum, lajike, sato, satoindeksi, fagopyritolit, D-chiro-inositoli 


\section{Johdanto}

Vuonna 1924 Gösta Grotenfelt kirjoitti Maatalouden tietokirjassa, että 'tattarin sato vaihtelee maassamme suuressa määrin, ollen 610 - $1830 \mathrm{~kg}$ siementä hehtaarilta sekä 500 - $1500 \mathrm{~kg}$ varsia'. Sata vuotta sitten havaitut haasteet tattarin viljelyssä ovatkin edelleen samat. Myös odotettavissa olevat satomäärät ovat pysyneet lähes ennallaan! Syynä lienee se, ettei tattarin lajikejalostukseen ole Suomessa panostettu lainkaan, vaikka kasvi oli aikoinaan erityisen tärkeä kaskien ja hikevien peltomaiden ravintokasvi. Vielä 1900-luvun alussa tattaria viljeltiin noin 1000 hehtaarilla (Anon. 1924), mihin viljelyalat eivät ole sen jälkeen yltäneet 2000-luvun alun tattari-innostuksesta huolimatta. Vuonna 2007 tattaria viljeltiin vähän alle 500 hehtaarilla (TIKE 2007).

Tattarin viljelyn laajentamista puoltavat sekä ympäristölliset että ihmisen ravitsemuksen kannalta tärkeät tekijät. Kasvi on vaatimaton viljeltäväksi ja se on tehokas ravinteiden käyttäjä (Hakala ym. 2008). Pähkylän koostumus on ravitsemuksellisesti edullinen ja erityisesti sen valkuainen, tärkkelys, erilaiset sokerit sekä lukuisat sekundääriyhdisteet ovat kiinnostavia (Steadman ym. 2001). Esimerkiksi tattarille tyypillisen D-chiro-inositoli-sokerin (Ueda ym. 2005) ja valkuaisen (Tomotake ym. 2006) on todettu olevan hitaasti imeytyviä ja siksi tattarille voisi avautua mahdollisuus muun muassa diabeteksen, sydän- ja verisuonitautien ja ylipainon hallinnassa (Tomotake ym. 2006, Kawa ym. 2003).

Ulkomailla on tehty lajikejalostusta useiden vuosikymmenten aikana. Suomeen on saatu parempia lajikkeita lähinnä yksityisten viljelijöiden tuomina, mutta keskitettyä toimintaa uuden geeniaineksen saamiseksi meille ei ole ollut. Lajikkeiden uudistaminen on kuitenkin erityisen tärkeää ristipölytteisillä kasveilla, joiden sato- ja laatuominaisuudet muuttuvat nopeasti. Nykyisin tattari käytetään lähinnä pelkästään gluteenittoman ruokavalion raaka-aineena, mutta pähkylä soveltuisi tätä paljon laajemminkin käytettäväksi.

MTT:ssä vuosina 2003 - 2007 tehdyn Terveyttä tattarista -hankkeen yhtenä tavoitteena oli etsiä uusia, Suomeen paremmin soveltuvia lajikkeita. Suurempien ja tasaisempien satotoiveiden lisäksi tavoitteena oli selvittää, kuinka paljon lajikkeet sisältävät liukoisiin sokereihin kuuluvia fagopyritolisokereita ja vapaata $D$-chiro-inositolia.

\section{Aineisto ja menetelmät}

Vuonna 2003 ja 2007 tehdyt lajikekokeet suoritettiin Jokioisissa ja niissä oli mukana 21 Puolasta, Suomesta, Tšekistä ja Valko-Venäjältä saatua lajiketta. Koekaaviona käytettiin epätäydellistä latinalaista neliötä, jossa oli 21 riviä ja viisi saraketta (Cochran \& Cox 1957). Kentät kylvettiin kesäkuun alussa, jolloin keväthallojen vaara oli ohitettu. Kylvömääränä käytettiin 180 itävää siementä/ $\mathrm{m}^{2}$ ja lannoitteena $250 \mathrm{~kg}$ Kevätviljan Y3:sta (20:3:8). Kasvuston taimettumista, kukintaa sekä pähkylän muodostusta havainnoitiin kasvukauden aikana. Juuri ennen sadonkorjuuta mitattiin pituudet sekä otettiin kasvustonäytteet satoindeksin laskemista varten. Sato puitiin syyskuussa 13,75 $\mathrm{m}^{2}$-suuruiselta alalta. Ruutu- ja hehtaarisatojen laskemiseksi kuivatuista ja lajitelluista siemenistä määritettiin ensin roska- ja kosteuspitoisuus. Lopullinen puhdas sato ilmoitetaan pähkylän $15 \%$ :n kosteudessa. D-chiro-inositolia sisältävät fagopyritolit sekä muut liukoiset sokerit analysoitiin kuivatuista ja kuorituista pähkylöistä aikaisempaa määritysmenetelmää jonkin verran muunnellen (Steadman ym. 2000).

\section{Tulokset ja tulosten tarkastelu}

\section{Pähkyläsadot}

Kaikki kokeessa olleet lajikkeet taimettuivat, alkoivat kukkia ja tuottivat tuleentuneita pähkylöitä ennen syyshalloja. Kukinta alkoi molempina koevuosina lajikkeesta riippumatta noin heinäkuun puolessa välissä. Sen sijaan fenotyyppiset ominaisuudet kuten kukinnan runsaus, kasvien pituus ja pähkylöiden ulkonäkö vaihtelivat lajikkeiden välillä.

Vuodet 2007 ja 2007 olivat satomääriltään hyvin erilaiset. Vuonna 2003 keskimääräiset ruutusadoista lasketut hehtaarisadot vaihtelivat 636 - $1319 \mathrm{~kg}: \mathrm{n}$ ja vuonna 2007612 - $2233 \mathrm{~kg}: \mathrm{n}$ välillä. Verranteena käytettiin Etelä-Suomessa pitkään viljeltyä 'Ilkka'-paikalliskantaa, joka tuotti 
ensimmäisenä koevuonna 1106 ja toisena $1618 \mathrm{~kg} / \mathrm{ha}$. Vuonna 2003 vain valkovenäläiset 'Karmen' $(1319 \mathrm{~kg} / \mathrm{ha}) \mathrm{ja}$ 'Anita' (1251 kg/ha) tuottivat merkitsevästi suuremman sadon 'Ilkkaan' verrattuna $(\mathrm{p}<0.05)$. Sen sijaan vuonna 2007 'Ilkkaa' enemmän $(\mathrm{p}<0.05)$ tuottavien 'Anitan' $(2233 \mathrm{~kg} / \mathrm{ha})$ ja 'Karmenin' (2054 kg/ha) lisäksi myös puolalaiset 'Luba' (2036 kg/ha), Kora' (2016 kg/ha), 'Panda' (1997 kg/ha) sekä valkovenäläiset 'Vlada' (1984 kg/ha) ja 'Zadanne' (1875 kg/ha) olivat erityisen satoisia. 'Ilkkaa' heikompisatoiset $(\mathrm{p}<0.05)$ tuottivat vuonna 2003 alle $863 \mathrm{~kg} / \mathrm{ha}$ (seitsemän lajiketta) ja vuonna 2007 alle $1156 \mathrm{~kg} / \mathrm{ha}$ (neljä lajiketta).

Tattarin satotasojen vaihteluista on tiedetty jo pitkään (Grotendelt 1924) ja edelleen vaihtelut voivat olla suuria. Suotuisina vuosina satoa voidaan odottaa $2000 \mathrm{~kg} / \mathrm{ha}$ (Ansalehto \& Keskitalo 2007), mutta hyvänä voidaan pitää jo $1200 \mathrm{~kg} / \mathrm{ha}$ (Montonen \& Kontturi 1997). Aikaisempaan satotasoon verrattuna, nyt tutkimuksessa mukana olleet parhaat lajikkeet ovat varteenotettavia uusia tulokkaita, joilta voidaan odottaa kohtuullisia satoja myös heikoimpina satovuosina. Saksalaisessa tattaritutkimuksissa hehtaarisadoiksi mainitaan runsaat $1500 \mathrm{~kg}$ (Schulte auf'm Erley ym. 2005), joten Suomessa odotettavissa olevat kilomäärät ovat hyvinkin Keski-Eurooppaan nähden kilpailukykyisiä. Tattarin ulkomailla tehtävä lajikejalostus suoltaa kuitenkin jatkuvasti parempisatoisia lajikkeita, joita tulisi voida jatkossa hyödyntää myös meillä.

\section{Satoindeksit}

Tattarilajikkeista lasketut satoindeksit vaihtelivat lajikkeesta riippuen $0.14-0.28$ välillä. Satoindeksi (pähkylä g/kasvin koko biomassa g) kuvaa kasvin tuottaman siemensadon suhdetta koko massaan. Sadoltaan parhaat lajikkeet sijoittuivat satoindekseinä ilmaistuna myös parhaimmistoon ja sadoltaan huonoimmat viimeisimmiksi. Vuonna 2003 parhaan sadon tuottaneilla 'Karmen' ja 'Anita' 'lajikkeilla satoindeksit olivat 0.28 ja 0.23 sekä verranteena olleella 'Ilkalla' 0.25 . Satoindeksin suuruus ei näyttänyt riippuvan pituudesta lyhyiden ja keskipitkien lajikkeiden kohdalla. Sen sijaan pisimmillä lajikkeilla satoindeksit olivat pienimpiä, koska nämä myös olivat pähkyläsadoltaan huonoimpia. Saksassa tehdyissä kokeessa tattarin satoindeksiksi saatiin $0.29-0.33$. Vaihteluun vaikuttivat typpilannoitus sekä lajike. Hehtaarille annetun lannoituksen lisääminen 30:sta $60 \mathrm{~kg}$ :aan pienensi tattarin satoindeksiä merkitsevästi, kun taas muille kasveille vaikutus oli päinvastainen (Schulte auf'm Erley ym. 2005). Jo kohtuullinen määrä typpeä $(>40-50 \mathrm{~kg} / \mathrm{ha})$ on havaittu myös Suomessa rehevöittävän kasvustoa ja lisäävän pituuskasvua pähkylöiden kustannuksella (Montonen \& Kontturi 1997).

\section{Liukoiset sokerit}

Liukoisten sokereiden kuten vapaiden D-chiro-inositolien, fagopyritolien (A1, B1, A2, B2, ja B3), myo-inositolien, glukoosin, raffinoosin ja galaktinolien keskimääräiset pitoisuudet olivat 510 $720 \mathrm{mg} / 100 \mathrm{~g}$ lajikkeesta riippuen. Huomioitavaa on se, että laskuissa ei ole mukana sakkaroosia. Fagopyritolien yhteismääräksi saatiin $346-617 \mathrm{mg} / 100 \mathrm{~g}$, josta fagopyritoli B1:stä oli eniten, yleensä noin $70 \%$. Tattarissa $D$-chiro-inositolia on sekä vapaana että fagopyritolien galaktosyyleihin liittyneenä ja laskennallisesti inositolien yhteismääräksi saatiin 192 - 324 mg/100g lajikkeesta riippuen.

Kun tarkasteltiin pähkyläsatojen ja D-chiro-inositolien riippuvuutta havaittiin, että lajikkeet jakaantuvat kahteen ryhmään. Toisen muodostivat ne, joiden pähkyläsato erosi merkitsevästi verranteena olleesta 'Ilkasta', ja joiden kesimääräinen sato jäi alle $863 \mathrm{~kg} / \mathrm{ha}$ (seitsemän lajiketta) ja toisen muodostivat yli $863 \mathrm{~kg} /$ ha tuottaneet lajikkeet (14 lajiketta). Suurimmat fagopyritolimäärät mitattiin sadoltaan heikommasta ryhmästä ja vastaavasti pienimmät fagopyritolimäärät sadoltaan paremmasta ryhmästä.

Tuloksemme ovat Yhdysvalloissa tehdyn tutkimuksen kanssa vertailukelpoisia. Eri sokerifraktioiden yhteismäärät olivat tutkimuksessa seuraavat: liukoiset sokerit (ilman sakkaroosia) $640 \mathrm{mg} / 100 \mathrm{~g}$, fagopyritolit $565 \mathrm{mg} / 100 \mathrm{~g}$ ja D-chiro-inositolit $287 \mathrm{mg} / 100 \mathrm{~g}$. Fagopyritoli B1:n osuus kokonaisfagopyritoleista oli vähän alle $70 \%$ (Steadman ym. 2000). Fagopyritolien oletetaan osallistuvan jollakin tavalla siementen tuleentumiseen ja itämiseen, ja pitoisuuksien havaittiin riippuvan kasvatuslämpötilasta. Viileässä $\left(18{ }^{\circ} \mathrm{C}\right)$ tuleentuneet pähkylät sisälsivät sokereita yli kaksinkertaisesti lämpimässä $\left(25^{\circ} \mathrm{C}\right)$ varttuneisiin verrattuna (Horbowicz ym. 1998). Terveellisiä ainesosia sisältävän tattarin viljely olisi siten yhä kiinnostavampaa Suomen kasvuoloissa, jotka ainakin toistaiseksi ovat Keski-Eurooppaa viileämmät. 


\section{Johtopäätökset}

Muiden maiden kasvuoloihin jalostettuja tattarilajikkeita voidaan tutkimuksen mukaan viljellä onnistuneesti myös Suomessa. Kahtena koevuotena kokeissa olleiden lajikkeiden joukosta erottui nykyisin Suomessa viljeltäviä paikalliskantoja satoisampia jalosteita. Erityisesti 'Karmen' ja 'Anita' ovat varteenotettavia lajikkeita, koska ne tuottivat merkitsevästi suurempia satoja molempina koevuosina. Valkovenäläisten jalosteiden lisäksi myös tutkimuksen puolalaiset lajikkeet olivat toisena koevuotena hyviä. Suuren hehtaarisadon tuottaville lajikkeille oli ominaista, että ne löytyivät yleensä matalien ja keskipitkien lajikkeiden joukosta, joiden satoindeksi oli myös suurin. Ravitsemuksellisesti mielenkiintoisia liukoisia sokereita kuten fagopyritoleja ja $D$-chiro-inositolia voidaan Suomessa tuottaa vertailukelpoisesti ulkomaisiin tuloksiin verrattuna. Koska hitaasti imeytyviä tattarisokereita saattaa olla vähemmän runsassatoisissa lajikkeissa, on tämä huomioitava lajikevalintoja tehtäessä.

\section{Kirjallisuus}

Anon. 1924. Pelto- ja niittyala ja niiden käyttö 1920 ja 1921. Suomen virallinen tilasto III. Maatalous 18 , Maanviljelys ja karjanhoito vuonna 1921. s. 2-4.

Ansalehto, A., Keskitalo, M. 2007. Tattari. In: Toimitus: Marjo Keskitalo, Kaija Hakala, Sari Peltonen, Taina Harmoinen. Erikoiskasvien viljely. ProAgria Maaseutukeskusten Liiton julkaisuja 1034: Tieto tuottamaan 118: p. $82-87$.

Cochran, W.G., Cox, G. M. 1957. Experimental Designs. Second ed., John Wiley \& Sons, New York, 611 pp. Grotenfelt, G. 1924. Suomalainen peltokasviviljelys II. Teoksessa: Arola, T., Bredenberg, G.A., Enckell, K., Grotenfelt, G., Nylander, H, Sunila, J.E. \& von Wendt, G. (toim.). Maatalouden Tietokirja. s. 118-122.

Hakala, K., Keskitalo, M., Eriksson, C. ja Pitkänen, T. 2008. Diversity in root volume, root and shoot development and mineral content of nine underutilised crops. Manuscript (submitted).

Horbowicz, M., Brenac, P. \& Obendorf, R.L. 1998. Fagopyritol B1, O- $\alpha$-D-galactopyranosyl-(1 $\rightarrow 2)$-D-chiroinositol, a galactosyl cyclitol in maturating buckwheat seeds associated with desiccation tolerance. Planta 205: 111.

Kawa, J.M. Taylor, C.G., Przybylski, R. 2003. Buckwheat concentrate reduces serum glucose in Streptozotocin-diabetic rats. J. Agric Food Chem 51: 7287-7281.

Montonen, R. \& Kontturi, M. 1997. Tattarin viljelytekniikka. Maatalouden tutkimuskeskus, 51 s.

Schulte auf'm Erley, G., Kaul, H.-P., Kruse, M. \& Aufhammer, W. 2005. Yield and nitrogen utilization efficiency of the pseudocereals amatanth, quinoa, and buckwheat under differing nitrogen fertilization. Europ. J. Agronomy 22: 95-100.

Steadman, K.J., Burgoon, M.S., Schuster, R.L., Lewis, B.A., Edwardson, S.E., Obendorf, R.L. 2000. Fagopyritols, D-chiro-inositol, and other soluble carbohydrates in buckwheat seed milling fractions. J. Agric Food Chem 48: 2843-2847.

Steadman, K.J., Burgoon, M.S., Lewis, B.A., Edwardson, S.E., Obendorf, R.L. 2001. Buckwheat seed milling fractions: description, macronutrient composition and dietary fibre. Journal of Cereal Science 33: 271278.

TIKE 2007. Maa- ja Metsätalousministeriön Tietopalvelukeskus. Tilatut tiedot viljelykasvien pinta-aloista 2007, saatu 8.8.2007.

Tomotake, H., Yamamoto, N., Yanaka, N, Ohinata, H., Yamazaki, R., Kayashita, J., Kato, N. 2006. High protein buckwheat flour suppress hypercholesterolemia in rats and gallstone formation in mice by hypercholesterolemic diet and body fat in rats because of its low protein digestibility. Nutrition 22: 166-173.

Ueda, T., Coseo, M.P., Harrell, T.J., Obendorf, R.L. 2005. A multifunctional galactinol synthase catalyzes the synthesis of fagopyritol A1 and fagopyritol B1 in buckwheat seed. Plant Science 168: 681-690. 